\title{
Advances in the pathogenesis of Alzheimer's disease: a re-evaluation of amyloid cascade hypothesis
}

Suzhen Dong ${ }^{1,2,3}$, Yale Duan ${ }^{3}$, Yinghe $\mathrm{Hu}^{1,2,3}$ and Zheng Zhao ${ }^{3^{*}}$

\begin{abstract}
Alzheimer's disease (AD) is a common neurodegenerative disease characterized clinically by progressive deterioration of memory, and pathologically by histopathological changes including extracellular deposits of amyloid-beta (A-beta) peptides forming senile plaques (SP) and the intracellular neurofibrillary tangles (NFT) of hyperphosphorylated tau in the brain. This review focused on the new developments of amyloid cascade hypothesis with details on the production, metabolism and clearance of A-beta, and the key roles of some important A-beta-related genes in the pathological processes of AD. The most recent research advances in genetics, neuropathology and pathogenesis of the disease were also discussed.
\end{abstract}

Keywords: Alzheimer's disease, A-beta, APP, BACE1, Presenilins, ApoE, Neprilysin/insulin-degrading enzyme

\section{Review}

Introduction

Alzheimer's disease $(\mathrm{AD})$ was originally described by Alois Alzheimer in 1906 and was renamed several years later by Emil Kraepelin [1]. AD is characterized clinically by progressive deterioration of memory, and pathologically by histopathological changes including extracellular deposits of amyloid- $\beta$ (A $\beta)$ peptides forming senile plaques (SP) and the intracellular neurofibrillary tangles (NFT) of hyperphosphorylated tau in the brain, which are commonly regarded as the hallmarks of the disease.

Epidemiological studies have shown that $\mathrm{AD}$ is the leading cause of dementia, accounting for about $50 \%$ of all cases worldwide [2]. Aging is the most obvious risk factor for developing AD. It was estimated that the ageassociated prevalence rate of AD would be doubled every 5 years in the patients beyond 65 years of age [3]. In addition to aging, several other possible biological (such as genetic alterations and polymorphisms, and abnormal immune or inflammatory responses) and environmental factors (such as education, traumatic injury, oxidative

\footnotetext{
* Correspondence: zzhao@brain.ecnu.edu.cn

${ }^{3}$ Key Laboratory of Brain Functional Genomics, Ministry of Education, Shanghai Key Laboratory of Brain Functional Genomics, East China Normal University, 3663 Zhongshan Road (N), Shanghai 200062, China Full list of author information is available at the end of the article
}

stress, drugs, and hormone replacement) and the interactions among these factors have been considered to be contributors to a common pathway leading to $\mathrm{AD}[4,5]$.

Despite the remarkable improvements in our understanding of the pathogenesis of the disease have been made over last several decades, the accurate mechanism of $\mathrm{AD}$ remains unclear. Several independent hypotheses have been proposed to address the pathological lesions and neuronal cytopathology in connection with apolipoprotein E (ApoE) genotyping, hyperphosphorylation of cytoskeletal proteins, oxidative stress, abnormal cell cycle re-entry, inflammation and $A \beta$ metabolism. The amyloid metabolic cascade and the posttranslational modification of tau protein are considered to be the most important hypotheses in $\mathrm{AD}$, although none of them or other theories alone is sufficient to explain the diversity of biochemical and pathological abnormalities of AD, which is believed to involve a multitude of cellular and biochemical changes [3]. According to amyloid cascade hypothesis [6,7], accumulation of extracellular senile plaques made primarily by deposits of $A \beta$ peptide is thought to be one of the most prominent pathogenenic mechanisms of AD. Although the direct causal link between $A \beta$ and impaired neuronal function and memory is still under elucidation, it is undoubted that $A \beta$ plays a critical role in the neuropathology of $\mathrm{AD}$. This review focuses on the new 
developments of amyloid cascade hypothesis and its relevance to the most recent research advances in the genetics, neuropathology and pathogenesis of $\mathrm{AD}$. In the following sections, the recent progress of the studies on genes (see Figure 1) identified to be involved in the production, deposition and degradation of $A \beta$, the possible contributions of different $A \beta$ assemblies to $A D$, and their pathological functions are reviewed.

\section{$A \beta$-related genes}

\section{Amyloid precursor protein (APP)}

APP is an integral membrane glycoprotein expressed in the brain and central nervous system (CNS). It can undergo sequential proteolytic processing by two pathways: the $\alpha$ pathway and the $\beta$ pathway. In most cases, APP is sequentially cleaved via $\alpha$ pathway by $\alpha$ secretase and $\gamma$-secretase. The $\alpha$-secretase cleavage of APP is non-amyloidogentic, whereas the $\beta$ pathway leads to $A \beta$ generation. In the $\beta$ pathway APP is initially cleaved by $\beta$-secretase to release sAPP $\beta$ into extracellular space and leave the 99-amino-acids C-terminal fragment (C99) within the membrane. C99 is subsequently processed to 38-43 amino acids by $\gamma$-secretase to release $A \beta$ and APP intracellular C-terminal domain (AICD) [8]. In most cases, the $\gamma$-cleavage produces $A \beta 40$, while it could also generate a more toxic variant, $A \beta 42$. It has been recently found that $\gamma$-secretase activity for $A \beta$ production could be also negatively regulated by

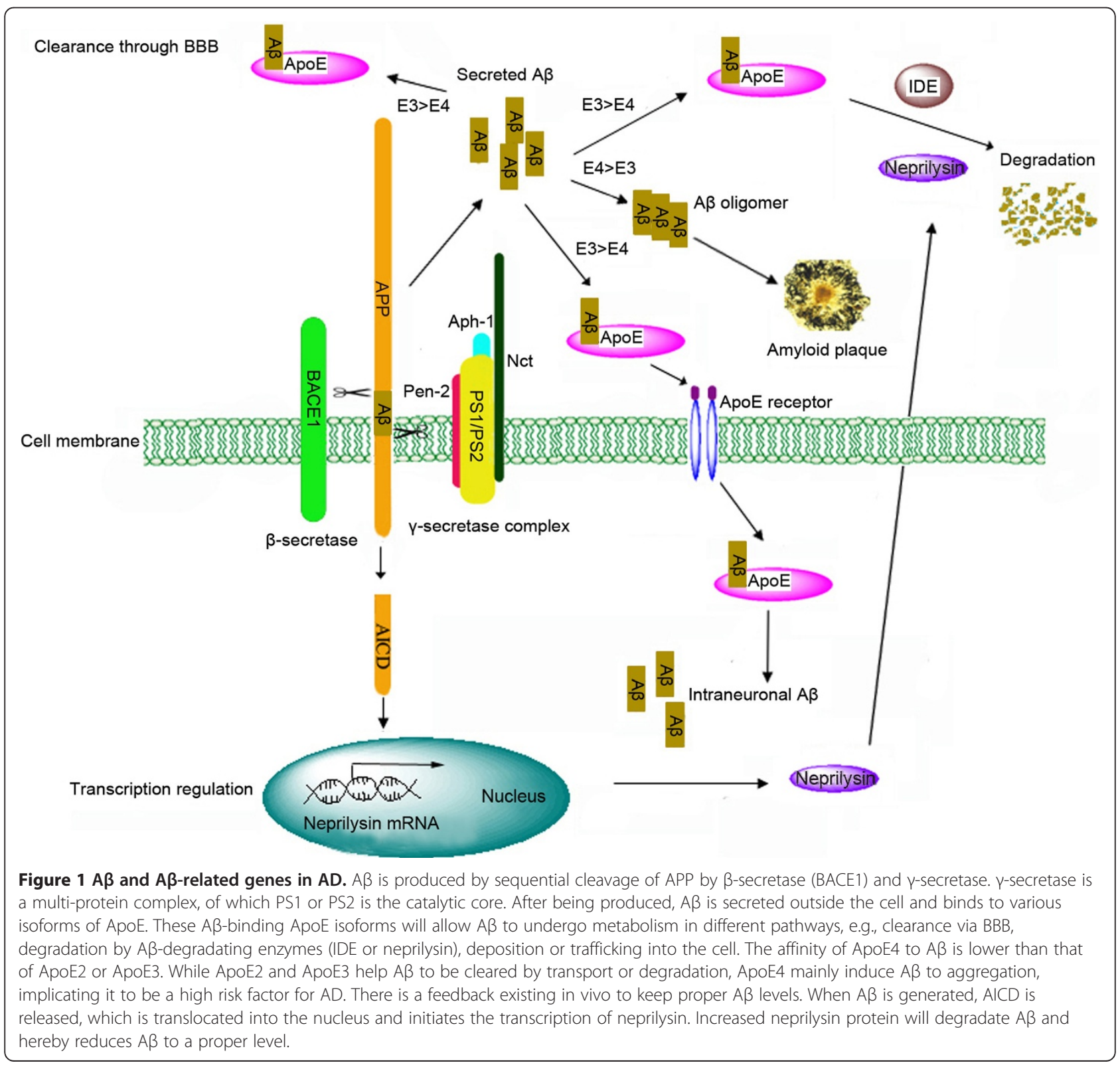


$\alpha$-secretase, indicating a cross-talk between the $\alpha$ pathway and the $\beta$ pathway [9].

\section{Physiological functions}

Although APP has been implicated in the pathology of $\mathrm{AD}$, much evidence shows that APP has its own physiological functions, especially in regulation of synaptic function and neuronal activity. Mice lacking APP and APP-like protein 2 show deficits in structure and function in neuromuscular synapses [10]. In cultured hippocampal neurons, lack of APP also affects synapse formation and transmission [11]. On the contrary, mice overexpressing APP exhibit enhanced synaptic plasticity and spatial memory [12]. Kamenetz et al found that APP processing could have a normal negative feed-back function in modulating $A \beta$ levels to maintain proper neuronal activity [13]. In addition, APP processing also regulates cholesterol metabolism. When $A \beta$ is produced, AICD is stabilized by Fe65, localized to the nucleus and binds to transcription factor Tip60. The protein-protein interaction initiates the transcription of the $A \beta$ degradation enzyme, neprilysin, thus reduces the $A \beta$ levels [14]. AICD-Fe65-Tip60 complex has been shown to suppress the transcription of lipoprotein receptor LRP1, which is known to regulate ApoE and cholesterol levels in CNS, suggesting a biological interaction between APP and ApoE/cholesterol metabolisms [15]. Furthermore, APP possesses the biological function in controlling cholesterol biosynthesis and sphingomyelin production via $A \beta$-dependent modulation of neuronal levels of Hydroxymethylglutaryl-CoA reductase (HMGR) and sphingomyelinases (SMases), indicating a functional basis of APP processing for the link between lipids and AD [16]. Endogenous AICD in primary neurons is temporally up-regulated during neuronal differentiation, and such a physiological function is negatively mediated by neuron-specific c-Jun N-terminal kinase JNK3 via phosphorylation of APP [17]. APP and its mammalian paralogs, the amyloid precursor-like proteins 1 and 2, have been demonstrated to be capable of forming homo- and hetero-complexes that exhibit physiological function in promoting trans-cellular adhesion in vivo [18]. Han et al also characterized a neuroprotective function of APP in preventing tau hyperphosphorylation via suppressing overactivation of Cdk5 (Cyclin-dependent kinase 5) [19].

\section{Pathological functions}

It is well known that the pathologcial function of APP lies on its amyloidogenic processing. It has been recognized that many APP mutations cause autosomal dominant early-onset AD. Increasing of gene copy number including genomic duplication in the APP locus [20,21] may also lead to AD dementia in earlier life. Interestingly, a recently identified mutation adjacent to $\beta$-site
(A673T) of APP gene was shown to result in A $\beta$ reduction and protection against cognitive decline in the elderly without $\mathrm{AD}$ [22]. On the other hand, however, overexpression of FAD-linked mutant APP could lead to olfactory sensory neuron apoptosis in the absence of amyloid plaque, which might be the mechanism of deficits in odor detection, one of the earliest AD symptoms [23]. All these indicate that both APP genomic duplication and mutations can lead to changes in APP function and subsequent $A \beta$ metabolism, strongly implicating a central role of not only APP but also its $\beta$-cleavage in pathogenesis of AD. To identify the pathological functions of APP, many APP transgenic mice including wildtype human APP and FAD-linked APP mutations have been generated. FAD-linked APP mutation mice show an increase in the amount, length, and fibrillogenic generation of $A \beta$ species and have amyloid deposits at the age of 18 months [24] while, surprisingly, mice overexpressing APP do not develop AD pathologies or memory deficits but instead exhibit enhanced spatial memory, which depends on the function of AICD generated by $\beta$ secretase-mediated cleavage [12]. Studies on APP mutation transgenic mice have given us much information of $\mathrm{AD}$ pathogenesis, but the molecular mechanisms still need further investigation.

\section{Beta-site APP cleaving enzyme 1 (BACE1)}

BACE1 is known as the major $\beta$-secretase to cleave APP at $\beta$-site to produce $\beta$-CTF for $A \beta$ generation in neurons [25]. BACE1 and its homolog, BACE2, have different transcriptional regulations and functions. BACE1 knockout mice are almost normal without $A \beta$ generation [26], and BACE1 deficits can rescue the memory impairment and cholinergic dysfunction in mutant human APP transgenic mice [27]. Repetto et al demonstrated that overexpression of BACE1 in H4 human cells can regulate APP intracellular signaling by interaction with the ShcA adaptor protein [28]. BACE1-mediated $\beta$-cleavage has been showed to be physiologically modulated by different spliced transcripts [29] and the activation of protein kinase C [30]. Impaired intracellular calcium homeostasis may stimulate BACE1 gene expression via nuclear factor of activated T cells 1 (NFAT 1) signaling pathway, leading to accelerated production of $A \beta$ [31]. BACE1 could be modulated by $A \beta 42$, but not $A \beta 40$, via an NFKB-dependent signaling pathway [32], and $A \beta 42-$ positive plaques could increase BACE1 levels in surrounding neurons before neuron loss occurs [33]. A $\beta 42$ could also induce expression of BACE1-antisense transcript, a natural regulator of BACE1 expression, which increased BACE1 mRNA stability [34]. Thus, increased BACE1 levels might be a positive feedback for $A \beta 42$ to initiate the amyloidogenesis of AD. In addition, BACE1dependent cleavage of low density lipoprotein receptor- 
related protein (LRP) can mediate the endocytosis of APP and ApoE [35] and has been suggested to be involved in the pathology of AD.

\section{Presenilin (PS) 1 and 2}

PS is an eight membrane-spanning protein with an $\mathrm{N}$ terminus, a 'loop' domain between transmembrane (TM) domain six and seven, and a C-terminus that is oriented toward the cytoplasm. Aspartate residues at position D275 (in TM6) and D385 (in TM7) are critical for PS function [36]. There are two PS genes: PS1 and PS2. PS, nicastrin, aph-1, and pen-2 form the active $\gamma$-secretase complex while PS is the catalytic core of the complex [37]. $\gamma$-secretase cleaves not only APP but many other type I transmembrane proteins (such as Notch, cadherins and LRP) as well [38], strongly implicating PS in both AD pathogenesis and many other neuronal physiological activities including development, calcium homeostasis and apoptosis.

\section{PS gain of function}

PS1 mutations are the most common genetic cause for early-onset familial AD (FAD). PS genes harbor about $90 \%$ of identified FAD mutations. There have been more than 100 PS1 mutations being described. Some of them, such as L85P, P117L, P117S, insF1, and L166P, are associated with very early onset (usually before age of 30 years old) of cognitive decline [39]. Many of the PS1 mutations lead to an increase in relative production of more toxic $A \beta 42$ peptides. The prevailing amyloid hypothesis posits that deposits of $A \beta$ peptides, especially the more hydrophobic and aggregation-prone $A \beta 42$, initiates a pathogenic cascade, leading to neurodegeneration in AD [40]. This has been referred to as the toxic gains-of-function of PS in triggering neurodegeneration in $\mathrm{AD}$. The amyloid cascade hypothesis is supported by the results from FAD-linked mutant transgenic mice. PS1 mutation significantly accelerates the rate of $A \beta$ deposition in mutant APP transgenic mice [24]. Expression of human mutant PS1 in PS1 null mice is sufficient to elevate $A \beta 1-42$, supporting a gain-of-function activity of PS1 mutation [41].

\section{PS loss of function}

However, the most recent evidence from several independent PS transgenic model-based studies emerged that supports the "PS loss of function" hypothesis as a potential pathogenic mechanism of AD. Firstly, mice lacking both PSs in the forebrain show AD-like progressive neurodegenerative phenotypes including forebrain degeneration, impaired synaptic plasticity and spatial memory without $A \beta$ production [42-46]. A number of PS1 mutations (L113P, G183V and insR352) have been found in patients with familial forms of frontotemporal dementia (FTD), a common neurodegenerative dementia that lacks amyloidogenesis [47-49]. These observations suggest that neurodegeneration can take place in the absence of $A \beta$.

PS genes have been identified to play an important role in many normal physiological activities. These physiological functions can be classified to $\gamma$-secretasedependent and -independent functions. There are many identified $\gamma$-secretase substrates. By cleavage of these substrates, PSs mediate their multiple functions in development, calcium homeostasis, cell adhesion, transport, trafficking/localization, and apoptosis [36,38,50]. FADlinked PS mutations might impair the $\gamma$-secretasedependent proteolysis of some of the substrates, such as Notch, N-cadherin and tyrosinase, resulting in loss of the related functions of PS [51,52]. Meanwhile, FAD-linked PS mutations might also impair some $\gamma$-secretase-independent functions, such as the regulation of $\beta$-catenin-dependent signaling [53], modulation of phosphatidylinositol 4,5-bisphosphate metabolism [54], endoplasmic reticulum $\left[\mathrm{Ca}^{2+}\right.$ ] leak function [55], PI3K/Akt signaling pathway-dependent neuroprotective roles [56], synaptic homeostasis [57] and fast axonal transport of APP [58]. In addition to involving in $A \beta$ generation, PS genes participate in the regulation of $A \beta$ degradation mediated by AICD-dependent transcriptional modulation of the degrading enzyme, neprilysin [14]. FAD-linked PS mutations may disrupt the physiological function of PSs in regulating $A \beta$ levels.

Surprisingly, many $\gamma$-secretase inhibitors at low concentration enhance $A \beta 42$ production while reducing A $\beta 40$ levels, similar to the effects of FAD-linked PS mutations [59-61], suggesting that PS mutation could result in a partial loss of its function. Furthermore, PS mutations are scattered throughout the protein's Nterminus, C-terminus and transmembrane domains, occurring at about $20 \%$ of the amino acid residues. As it is impossible for different PS mutations to gain the same toxic function, it is therefore most likely that the loss of normal PS function by 'random' changes of amino acid residues is the culprit for triggering $\mathrm{AD}$ pathogenesis. However, the "PS loss of function" hypothesis is still unable to explain the exact mechanism for FAD-linked APP mutations that cause AD. In this regard, it has been assumed that A 342 might act as an inhibitor of $\gamma$-secretase. APP mutations may interfere with the physiological roles of PS and hereby initiate the pathogenic cascades of $\mathrm{AD}$ [51]. Further investigations are required to confirm the hypothesis.

\section{Apolipoprotein E (ApoE) and other apolipoproteins}

Apolipoproteins play important roles in regulating $A \beta$ pathology. ApoE is the predominant apolipoprotein in the CNS and is synthesized and secreted mainly by 
astrocytes and microglias [62,63]. ApoE has critical roles in transporting lipids among CNS cells to keep lipid homeostasis, repairing injured neurons, maintaining synaptic connections, and scavenging toxins. ApoE gene encodes three alleles: ApoE2, ApoE3 and ApoE4. The alleles differ only in two residues at sites 112 and 158 . ApoE3 has Cys-112 and Arg-158, ApoE4 has arginine and ApoE2 cysteine at both sites. The differences between the alleles determine their distinct functions. ApoE2 is neuroprotective while ApoE4 is related to a variety of diseases.

It has been recognized that ApoE4 is the major genetic risk factor for sporadic AD. ApoE4 is associated with cognitive deficits [64], and the effect of ApoE4 is moderated by cholesterol levels [65]. In contrast to ApoE2 and ApoE3, ApoE4 is more sensitive to stress or injury, which causes neuron-specific proteolysis with the formation of a bioactive toxic C-terminal fragment [66]. Transgenic mice expressing high levels of carboxyl terminal-cleaved product ApoE4 (272-299) in the brain die 2-4 months after birth. The cortex and hippocampus of the transgenic mice display AD-like neurodegenerative alterations [67].

ApoE acts as the $A \beta$ chaperone and binds to different forms of $A \beta$, leading to changes in the structure, toxicity and deposition of $A \beta[68,69]$. Pharmacological blocking ApoE-A $\beta$ interaction can significantly reduce the formation of amyloid plaques and attenuate the deficits of memory in the transgenic mice carrying a Swedish K670L/M671L APP mutation (APP SWE $_{\text {) or a K670L/ }}$ M671L APP plus a PS1 M146L mutation (APP SWE $_{\text {PS1) }}$ [70]. The effects of ApoE on $A \beta$ depositions are supported by the observation that intake of sugar-sweetened water induces amyloidosis and memory impairment and increases ApoE levels in the brain of a transgenic mouse model of AD [71]. Besides, it is recently demonstrated that increased expression of ApoE by the retinoid $\mathrm{X}$ receptors agonist results in enhanced clearance of soluble $A \beta$ and reduced $A \beta$ plaque, and leads to reversal of cognitive deficits and improvement of synaptic functions in an AD mouse model [72]. Nevertheless, increasing evidence suggests that the regulatory effect of ApoE on $\mathrm{A} \beta$ deposition appears to be isoform-specific (ApoE4 > ApoE3 > ApoE2) and gene dosage-related [73]. ApoE promotes the proteolytic degradation of $A \beta$ by modulating the activity of $\mathrm{A} \beta$ degrading enzyme, which depends on $A p o E$ isoform structure and the lipidation status $[69,74]$. ApoE also participates in the regulation of $A \beta$ production through LRP pathway [75]. Given that APP processing is dependent on membrane cholesterol levels and that ApoE is the transporter of cholesterol [76], ApoE might therefore be a important player in $A \beta$ generation. In fact, it has been reported that activation of the amyloid cascade may isoform-specifically induce lysosomal activation and neurodegeneration of hippocampal CA1, entorhinal and septal neurons, which are responsible for the marked cognitive deficits in apolipoprotein transgenic mice [77]. ApoE4-induced impairments of neuroplasticity following environmental stimulation are also found to be mediated by intraneuronal oligomerized $A \beta$ [78]. Furthermore, C-terminal fragment of ApoE could induce tau phosphorylation in neurons that represents another character in AD brain, depending on both the isoform and cellular source of ApoE $[67,79]$.

In addition to ApoE, other apolipoproteins, such as ApoA-IV, were also found to regulate $A \beta$ metabolism. Genetic ablation of ApoA-IV in an AD mouse model accelerates $A \beta$ deposition, neuron loss and cognitive impairment [80].

\section{Neprilysin/insulin-degrading enzyme}

While familial early-onset $A D$ is associated with increased $A \beta$ production, defective $A \beta$ degradation may be involved in late-onset $\mathrm{AD}$ (LOAD), which constitutes approximately $90 \%$ of all AD cases [81]. Many enzymes including, but not limited to, neprilysin (NEP) and insulin-degrading enzyme (IDE) have been implicated for a role in degrading $A \beta$ [82]. NEP and IDE are reduced in $\mathrm{AD}$, and increasing evidence indicates an involvement of them in the imbalance of $A \beta$ production and clearance relating to $\mathrm{AD}$ pathology.

\section{Neprilysin (NEP)}

NEP is a $90 \sim 110 \mathrm{kDa}$ plasma membrane glycoprotein of the neutral zinc metalloendopeptidase family that degrades enkephalins, endothelins, and $A \beta$ peptides [82]. Particularly, NEP is the major enzyme to degrade soluble extracellular $A \beta$ in the brain. Recent studies demonstrated that NEP levels decline in an age-dependent manner and inversely correlate with levels of insoluble $\mathrm{A} \beta$ in the temporal and frontal cortex of $\mathrm{AD}$ and normal brain $[83,84]$. NEP expression or activities are decreased significantly in $\mathrm{AD}$ brain $[85,86]$. The finding that possession of ApoE4 was related to obvious reduction in NEP levels [85] suggests that down-regulation of NEP might be implicated in $\mathrm{AD}$ pathogenesis.

The transcription of NEP has been demonstrated to be regulated by AICD which is released during the $A \beta$ generation [14]. There is a physiological negative feedback in vivo that keeps $A \beta$ homeostasis, in which $A \beta$ production could lead to translocation of AICD to nucleus and transactivation of NEP. NEP therefore has a role in governing the balance between $A \beta$ production and degradation. If such a balance is disrupted, $A \beta$ would come to be oligomerized and lead to formation of the fibrillar $A \beta$ protein (fA $\beta)$. The resulting $\mathrm{fA} \beta$ can inhibit the proteolytic activities of the proteases by binding to NEP and 
IDE [87], leading to the formation of a positive feedback that accelerates amyloid deposition. Indeed, studies on transgenic mice of $\mathrm{AD}$ have shown that NEP-mediated degradation of $\mathrm{A} \beta$ plays a key role in $\mathrm{AD}$ neurodegeneration and serves as a novel therapeutic approach to $\mathrm{AD}$ [88]. These findings also suggest that AD pathogenesis might result from deficits in $A \beta$ clearance. On the other hand, however, recent observations in drosophila demonstrated that NEP overespression could result in the inhibition of CREB-mediated transcription, agedependent axon degeneration and shortened lifespan [89]. Studies on crossing hAPP transgenic mice and NEP transgenic mice also showed that, although NEP overexpression inhibits plaque formation, it fails to reduce pathogenic $A \beta$ oligomers and improve the impaired learning and memory function [90].

\section{Insulin-degrading enzyme (IDE)}

IDE is an $110 \mathrm{kDa}$ zinc metalloendopeptidase that highly expresses in the liver, testis, muscle and brain [82]. The enzyme has been implicated in the pathogenesis of $\mathrm{AD}$ and type II diabetes due to its capabilities in degrading $\mathrm{A} \beta$, AICD [91,92], amylin, insulin and insulin-like growth factors [82]. IDE gene is located in chromosome 10 that is highly associated with later-onset AD (LOAD) [93]. Some genetic variants of IDE have also been strongly implicated in LOAD [94,95]. IDE mRNA and protein levels are markedly decreased in hippocampus of AD patients with ApoE 64 allele, the genotyping known as a high risk factor for LOAD [96]. Membrane-bound IDE levels and its activity are significantly decreased in subjects with mild cognitive impairment (MCI) and appear to decrease continuously during the conversion from MCI to AD [97]. IDE activity is reduced in affected versus unaffected subjects of three chromosome 10linked AD pedigrees, although no significant difference of IDE expression has been observed [98]. However, recent studies on transgenic AD mouse models showed that cortical IDE mRNA and protein levels are elevated in parallel with $A \beta 40$ and $A \beta 42$ generation [99]. In transgenic tg2576 mice, IDE expression is increased with age and is located around amyloid plaque as a result of $\mathrm{A} \beta$-induced inflammation [100]. This phenomena is similar to the observation that IDE is immunopositive in senile plaques in human AD brain [101]. Studies on triple-transgenic mice (hAPPswe/PS1 M146V/hTau P301L) showed that the expression of IDE was regulated by 17 beta-estrodiol via an ERbeta/PI3K pathway [102]. Unlike NEP that hydrolyzes both monomeric and oligomeric $A \beta$, IDE is found to degrade only soluble monomeric A $\beta$ [103]. A recent study by Llovera et al demonstrated that the catalytic domain of IDE could form a stable complex with $A \beta$, which might disrupt $A \beta$ clearance and facilitate AD neurodegeneration [104].
There have been also studies showing that IDE can cleave C-terminal domain of human acetylcholinesterase (hAChE) and trigger its conformational conversion from $\alpha$ to $\beta$-structure, which acts as the seed of $A \beta$ fibrils and enhances the rate of amyloid elongation [105]. This suggests an important role of IDE digestion of C-terminal domain of hAChE in amyloidogenic pathogenesis of AD.

IDE plays essential role in insulin homeostasis, implicating a close relationship between $\mathrm{AD}$ and type II diabetes (DM2). A large body of evidence has indicated that cognitive capacity is often impaired in patients with diabetes [106] while insulin resistance is a high risk factor of AD [107]. IDE knockout mice exhibit hallmarks of both AD and DM2 [92]. Diet-induced insulin resistance leads to increased $\gamma$-secretase activity and decreased IDE activity, resulting in elevated $A \beta 40$ and $A \beta 42$ levels in the brain of $\operatorname{Tg} 2576$ mice [108]. Further exploration of the underlying mechanism has shown that defective insulin receptor signaling may lead to up-regulation of $A \beta$ generation. Insulin resistance induced by intake of sucrose-sweetened water or a safflower oil-enriched diet exacerbates the $\mathrm{AD}$ pathology in transgenic $\mathrm{AD}$ animal models [71,109].

\section{$A \beta$ and neurodegeneration}

Although it has been widely accepted that $A \beta$ plays a central role in the onset and progression of AD pathology, it remains unclear whether soluble or insoluble A $\beta$ located in extracellular or intracellular is the culprit to impaired neuronal function and memory. Meanwhile, much progress based on neurotoxic lesion, pharmacological, genetic, and neurophysiological studies in recent years has led to identification of many new physiological and biological alterations, such as mitochondrial dysfunction, oxidative stress, synaptic transmission, axonal trafficking and membrane disruption, that are responsible for the functions of $A \beta$ with significant implications in developing $\mathrm{AD}[110,111]$. In the following sub-sections, we selectively review the present research status in characterization of neurotoxic form of $A \beta$, and in the pathological functions of $A \beta$ in synaptic dysfunction and neuronal inflammation.

\section{$A \beta$ : soluble or insoluble, extracellular or intracellular, which one is neurotoxic form to AD?}

In the last two decades, $A \beta$ hypothesis has been the focus of AD researches. According to the hypothesis, deposition of $\mathrm{A} \beta$ peptide is the primary cause of driving $\mathrm{AD}$ degeneration and all of the other pathological features including intracellular neurofibrillary tangles (NFT) and neuron loss are the downstream events of the amyloid cascade [40]. The hypothesis, however, has been challenged in recent years [112]. Appearance of large "cotton wool" plaques resulting from PS1 
mutations has been demonstrated to be associated with some special symptoms such as spastic paraparesis rather than early-onset AD [113]. Decreased dendritic spine density, impaired synaptic plasticity, and cognitive dysfunction occur long before amyloid depositions that appear at 18 months in Tg2576 mice [114]. Hippocampal neuron loss in AD mouse models has been observed both at the site of amyloid aggregation and in areas distant from plaques [115].

The classical view is that $A \beta$ is deposited extracellularly, however, emerging evidence from transgenic mice and human patients has indicated that this peptide can also be accumulated intraneuronally that contributes to AD pathogenesis [116]. A PS1 mutated transgenic mouse model with intracellular $A \beta$ accumulation but without amyloid plaques exhibits AD-like neurodegeneration [117]. Results from the triple-transgenic AD mouse model (hAPPswe/PS1 M146V/hTau P301L) showed that impaired synaptic plasticity and cognitive dysfunction occur prior to the apparent plaques, and are correlated with the accumulation of intraneuronal $A \beta$ in hippocampus and amygdale [118,119]. Intracellular $\mathrm{A} \beta$ has been found to accumulate before the generation of amyloid plaques in many other $\mathrm{AD}$ mouse models [120-124] and in human AD [20,21,125]. As mentioned above, overexpression of FAD-linked mutant APP alone could induce the apoptosis of olfactory sensory neuron and this neurodegeneration is reversible, suggesting that amyloid plaques are not necessary for AD neurodegeneration [23].

Evidence has also emerged that the soluble $A \beta$, but not amyloid plaques, initiates pathological cascade. $\mathrm{A} \beta$ dimmers derived from untreated human cerebrospinal fluid (CSF) suppress hippocampal synaptic plasticity in vivo [126]. Neuron exposure to prefibrillar $A \beta$ can cause tau-dependent microtubule disassembly [127]. A $\beta$ oligomers have been observed to disrupt calcium signaling [128], affect the function of NMDA receptor $[129,130]$, and induce oxidative stress [131] and mitochondrial dysfunction [132]. Furthermore, in vitro studies have demonstrated that $\beta$-sheet intermediate (I $\beta$ ) of A $\beta$ prior to fibril formation is more toxic than the fibrils [133]. It has also been shown that soluble $A \beta$ oligomers induce reduction in postsynaptic receptors and disruptions of synaptic morphology in cultured hippocampal neurons [134,135]. Notably, intracerebroventricular injection of AD brain-derived extracts containing soluble A $\beta$ could lead to obvious inhibition of hippocampal LTP in rats, supporting the role of SDS-stable $A \beta$ dimer in mediating synaptic plasticity disruption [136].

Pyroglutamate-amyloid- $\beta(\mathrm{pE} 3-\mathrm{A} \beta)$, an N-terminal truncated $A \beta$ species, has recently been found in $A \beta$ deposits specific to $\mathrm{AD}$ brain but absent in normal aging. Transgenic mice expressing this kind of truncated
A $\beta$ showed progressive neurodegeneration including neuron loss, impaired LTP, microglia activation and astrocytosis [137]. A signal transduction pathway of soluble $A \beta$ oligomer has recently been delineated, in which oligomeric $A \beta$ activates Fyn kinase by binding to cellular prion protein $(\mathrm{PrPc})$ and results in the phosphorylation of NR2B subunit of NMDA receptor, and eventually leads to dendritic spine loss and altered synaptic function [138].

In contrast to the observations mentioned above, Lesne et al identified the extracellular accumulation of a soluble $56-\mathrm{kDa} A \beta$ assembly (termed $A \beta * 56$ ) composed of $12 \mathrm{~A} \beta$ peptides that contributes to the memory impairment in Tg2576 mice [139]. This finding has been supported by others using transgenic mice with increased formation of amyloid plaques but reduced $A \beta * 56$ levels [140]. Taken together, although increasing data have been accumulated that strongly suggest the soluble $A \beta$ and intracellular $A \beta$ to be more suspicious in underlying $\mathrm{AD}$ pathogenesis, the involvement of extracellular $A \beta$ in pathologies of the disease is still not neglectable.

\section{Other pathological functions of $A \beta$ $A \beta$ and synaptic dysfunction}

$\mathrm{A} \beta$ has long been shown to affect excitatory synaptic neurotransmission [13] and hippocampal synaptic plasticity $[110,126,141]$. A $\beta$ oligomers are able to bind specifically to excitatory pyramidal neurons and affect their synaptic structure, composition and density and the membrane expression of NMDA receptor [135]. Similar observations on rat hippocampal slices have also shown that $A \beta$ oligomers induce loss of hippocampal synapses and spines in a NMDA receptor-dependent manner [130]. A $\beta$ exhibits a specific inhibitory role in a presynaptic P/Q calcium current, which is required for synaptic plasticity [128]. A $\beta$ also plays an important role in activity-dependent presynaptic vesicle release [142]. Moreover, $\mathrm{A} \beta$ can induce neuronal network dysfunction including abnormal induction of excitatory neuronal activity and compensatory inhibitory circuits [143]. The abnormalities of synapse and neuronal network resulting from $A \beta$ might be the physiological basis of cognitive decline in $\mathrm{AD}$ animal models and patients.

\section{$A \beta$ and inflammation}

Microglia is rapidly recruited around amyloid plaques after its appearance [144]. A $\beta$ can trigger the translocation of microglia from bone marrow to the sites around amyloid plaques [145]. A $\beta$ up-regulates P38 MAPK or p44/42 MAPK signaling, which may lead to microglia activation with release of cytokines including tumor necrosis factor $\alpha$ (TNF- $\alpha)$ and interleukin-1 $\beta$ (IL1- $\beta$ ) [146]. The microglia around plaques maintains the 
stability of the plaques [147]. Both pharmacological blockade and genetic knock-out of TNF- $\alpha$ or iNOS down-regulate $A \beta$-induced cognitive dysfunction in $A D$ mouse model, revealing that TNF- $\alpha$ and iNOS are key mediator of $A \beta$ neurotoxicity [148]. Genetic disruption of transforming growth factor $\beta$ (TGF- $\beta$ ) signaling mitigates $A \beta$ levels and amyloid plaques, and partially rescues the cognitive abnormality in $\operatorname{Tg} 2576$ mice [149]. However, the roles of TGF- $\beta$ signaling are in a debate. Tesseur I et al showed that deficiency in TGF- $\beta$ signaling promotes $A \beta$ accumulation and neuronal degeneration [150]. Accumulating evidence also suggests that functional loss of TGF- $\beta$ signaling may contribute to $\mathrm{A} \beta$-induced neurodegeneration and tau pathology, indicating a neuroprotective role of this pathway [151].

\section{Conclusion}

$\mathrm{AD}$ is a complex neurodegenerative disease involving the interactions among various potential biological and environmental factors. Among them, abnormal processes of $A \beta$ production, degradation and deposition have been strongly implicated in the underlying neuropathology and neuropathogenesis of familial earlieronset and sporadic later-onset forms of AD. Genes involved in these processes, including APP, BACE1, PS1/2, ApoE, NEP, IDE and so on, play important roles in $\mathrm{AD}$ initiation and progression. Further dissection with depth and breadth of genetic influences may help defining the precise mechanisms involved in the disease pathogenesis, and eventually leading to development of new arrays of therapeutics with symptomatic effects or disease-modifying potential.

\section{Abbreviations}

AD: Alzheimer's disease; AB: Amyloid- $\beta$; SP: Senile plaques; NFT: Neurofibrillary tangles; ApoE: Apolipoprotein E; CNS: Central nervous system; APP: Amyloid precursor protein; C99: C-terminal fragment; AICD: APP intracellular C-terminal domain; LRP1: Lipoprotein receptor-related protein; HMGR: Hydroxymethylglutaryl-CoA reductase; SMases: Sphingomyelinases; JNK: c-Jun N-terminal kinase; Cdk5: Cyclin-dependent kinase 5; FAD: Familiar Alzheimer's disease; BACE1: Beta-site APP cleaving enzyme 1; $\beta$-CTF: $\beta-C-$ terminal fragment; BACE2: Beta-site APP cleaving enzyme 2; NFAT 1: Nuclear factor of activated T cells 1; NRG1: Neuregulin 1; PS: Presenilin;

TM: Transmembrane; aph-1: Anterior pharynx-defective 1; pen-2: Presenilin enhancer 2; FTD: Frontotemporal dementia; PI3K: Phosphoinositide_3-kinase; Akt: Protein kinase B; NEP: Neprilysin; IDE: Insulin-degrading enzyme; ECEs: Endothelin-converting enzymes; ACE: Angiotensin-converting enzyme; MMPs: Plasmin and matrix metalloproteinases; LOAD: Later-onset AD; MCI: Mild cognitive impairment; ERbeta: Estrogen receptor beta; hAChE: Human acetylcholinesterase; DM2: Type II diabetes; PrPc: Cellular prion protein; MAPK: Mitogen-activated protein kinase; TNF-a: Tumor necrosis factor a.; IL1- $\beta$ : Interleukin-1 $\beta$; GSK3: Glycogen synthase kinase 3.
}

\section{Competing interests}

The authors declare that they have no competing interests.

\section{Authors' contributions}

SZ Dong and YL Duan collected the reference materials and drafted the manuscript. YH Hu and Z Zhao conceived of the study, and participated in its design and coordination and helped to draft the manuscript. All authors read and approved the final manuscript.

\section{Acknowledgements}

This work was supported by the grants from the National Natural Science Foundation of China (No. 31171019, No. 81173108 and No. 31000574), and the Opening Projects of Shanghai Key Laboratory of Brain Functional Genomics and Key Laboratory of Brain Functional Genomics (East China Normal University), Ministry of Education.

\section{Author details}

'Shanghai Engineering Research Center for Molecular Therapeutics and New Drug Development, East China Normal University, Shanghai 200062, China. ${ }^{2}$ Institute of Chemical and Translational Genomics, East China Normal University, Shanghai 200062, China. ${ }^{3}$ Key Laboratory of Brain Functional Genomics, Ministry of Education, Shanghai Key Laboratory of Brain Functional Genomics, East China Normal University, 3663 Zhongshan Road (N), Shanghai 200062, China.

Received: 15 August 2012 Accepted: 13 September 2012 Published: 21 September 2012

\section{References}

1. Möller HJ, Graeber MB: The case described by Alois Alzheimer in 1911. Eur Arch Psychiatry Clin Neurosci 1998, 248:111-122.

2. Mount C, Downton C: Alzheimer disease: progress or profit? Nat Med 2006, 12:780-784.

3. Bachman DL, Wolf PA, Linn RT, Knoefel JE, Cobb JL, Belanger AJ, White LR, D'Agostino RB: Incidence of dementia and probable Alzheimer's disease in a general population: the Framingham Study. Neurology 1993, 43:515-519.

4. Hardy J: The Alzheimer family of diseases: many etiologies, one pathogenesis? Proc Natl Acad Sci USA 1997, 94:2095-2097.

5. Small GW: The pathogenesis of Alzheimer's disease. J Clin Psychiatry 1998, 59(Suppl 9):7-14.

6. Hardy J: Alzheimer's disease: the amyloid cascade hypothesis: an update and reappraisal. J Alzheimers Dis 2006, 9:151-153.

7. Hardy JA, Higgins GA: Alzheimer's disease: the amyloid cascade hypothesis. Science 1992, 256:184-185.

8. Selkoe DJ: Normal and abnormal biology of the beta-amyloid precursor protein. Annu Rev Neurosci 1994, 17:489-517.

9. Tian Y, Crump CJ, Li YM: Dual role of alpha-secretase cleavage in the regulation of gamma-secretase activity for amyloid production. J Biol Chem 2010, 285:32549-32556.

10. Wang P, Yang G, Mosier DR, Chang P, Zaidi T, Gong YD, Zhao NM, Dominguez B, Lee KF, Gan WB, Zheng H: Defective neuromuscular synapses in mice lacking amyloid precursor protein (APP) and APP-Like protein 2. J Neurosci 2005, 25:1219-1225.

11. Priller C, Bauer T, Mitteregger G, Krebs B, Kretzschmar HA, Herms J: Synapse formation and function is modulated by the amyloid precursor protein. J Neurosci 2006, 26:7212-7221.

12. Ma H, Lesne S, Kotilinek L, Steidl-Nichols JV, Sherman M, Younkin L, Younkin S, Forster C, Sergeant N, Delacourte A, et al: Involvement of beta-site APP cleaving enzyme 1 (BACE1) in amyloid precursor protein-mediated enhancement of memory and activity-dependent synaptic plasticity. Proc Natl Acad Sci USA 2007, 104:8167-8172.

13. Kamenetz F, Tomita $T$, Hsieh H, Seabrook G, Borchelt D, Iwatsubo T, Sisodia S, Malinow R: APP processing and synaptic function. Neuron 2003, 37:925-937.

14. Pardossi-Piquard R, Petit A, Kawarai T, Sunyach C, da Alves Costa C, Vincent B, Ring S, D'Adamio L, Shen J, Muller U, et al: Presenilin-dependent transcriptional control of the Abeta-degrading enzyme neprilysin by intracellular domains of betaAPP and APLP. Neuron 2005, 46:541-554.

15. Liu Q, Zerbinatti CV, Zhang J, Hoe HS, Wang B, Cole SL, Herz J, Muglia L, Bu $\mathrm{G}$ : Amyloid precursor protein regulates brain apolipoprotein $\mathrm{E}$ and cholesterol metabolism through lipoprotein receptor LRP1. Neuron 2007, 56:66-78.

16. Grimm MO, Grimm HS, Patzold AJ, Zinser EG, Halonen R, Duering M, Tschape JA, De Strooper B, Muller U, Shen J, Hartmann T: Regulation of cholesterol and sphingomyelin metabolism by amyloid-beta and presenilin. Nat Cell Biol 2005, 7:1118-1123.

17. Kimberly WT, Zheng JB, Town T, Flavell RA, Selkoe DJ: Physiological regulation of the beta-amyloid precursor protein signaling domain by 
c-Jun N-terminal kinase JNK3 during neuronal differentiation. J Neurosci 2005, 25:5533-5543.

18. Soba P, Eggert S, Wagner K, Zentgraf H, Siehl K, Kreger S, Lower A, Langer A, Merdes G, Paro R, et al: Homo- and heterodimerization of APP family members promotes intercellular adhesion. EMBO J 2005, 24:3624-3634.

19. Han P, Dou F, Li F, Zhang X, Zhang YW, Zheng H, Lipton SA, Xu H, Liao FF: Suppression of cyclin-dependent kinase 5 activation by amyloid precursor protein: a novel excitoprotective mechanism involving modulation of tau phosphorylation. J Neurosci 2005, 25:11542-11552.

20. Cabrejo L, Guyant-Marechal L, Laquerriere A, Vercelletto M, De la Fourniere F, Thomas-Anterion C, Verny C, Letournel F, Pasquier F, Vital A, et al: Phenotype associated with APP duplication in five families. Brain 2006, 129:2966-2976.

21. Rovelet-Lecrux A, Hannequin D, Raux G, Le Meur N, Laquerriere A, Vital A, Dumanchin C, Feuillette S, Brice A, Vercelletto M, et al: APP locus duplication causes autosomal dominant early-onset Alzheimer disease with cerebral amyloid angiopathy. Nat Genet 2006, 38:24-26.

22. Jonsson T, Atwal JK, Steinberg S, Snaedal J, Jonsson PV, Bjornsson S, Stefansson H, Sulem P, Gudbjartsson D, Maloney J, et al: A mutation in APP protects against Alzheimer's disease and age-related cognitive decline. Nature 2012, 488:96-99.

23. Cheng N, Cai H, Belluscio L: In vivo olfactory model of APP-induced neurodegeneration reveals a reversible cell-autonomous function. J Neurosci 2011, 31:13699-13704.

24. Borchelt DR, Ratovitski T, van Lare J, Lee MK, Gonzales V, Jenkins NA, Copeland NG, Price DL, Sisodia SS: Accelerated amyloid deposition in the brains of transgenic mice coexpressing mutant presenilin 1 and amyloid precursor proteins. Neuron 1997, 19:939-945.

25. Cai H, Wang Y, McCarthy D, Wen H, Borchelt DR, Price DL, Wong PC: BACE1 is the major beta-secretase for generation of Abeta peptides by neurons. Nat Neurosci 2001, 4:233-234.

26. Luo Y, Bolon B, Kahn S, Bennett BD, Babu-Khan S, Denis P, Fan W, Kha H, Zhang J, Gong Y, et al: Mice deficient in BACE1, the Alzheimer's betasecretase, have normal phenotype and abolished beta-amyloid generation. Nat Neurosci 2001, 4:231-232.

27. Ohno M, Sametsky EA, Younkin LH, Oakley H, Younkin SG, Citron M, Vassar R, Disterhoft JF: BACE1 deficiency rescues memory deficits and cholinergic dysfunction in a mouse model of Alzheimer's disease. Neuron 2004, 41:27-33.

28. Repetto E, Russo C, Venezia V, Nizzari M, Nitsch RM, Schettini G: BACE1 overexpression regulates amyloid precursor protein cleavage and interaction with the ShcA adapter. Ann N Y Acad Sci 2004, 1030:330-338.

29. Mowrer KR, Wolfe MS: Promotion of BACE1 mRNA alternative splicing reduces amyloid beta -peptide production. J Biol Chem 2008, 283:18694-18701.

30. Wang L, Shim H, Xie C, Cai $\mathrm{H}$ : Activation of protein kinase $\mathrm{C}$ modulates BACE1-mediated beta-secretase activity. Neurobiol Aging 2008 , 29:357-367.

31. Cho HJ, Jin SM, Youn HD, Huh K, Mook-Jung I: Disrupted intracellular calcium regulates BACE1 gene expression via nuclear factor of activated T cells 1 (NFAT 1) signaling. Aging Cell 2008, 7:137-147.

32. Buggia-Prevot V, Sevalle J, Rossner S, Checler F: NFkappaB-dependent control of BACE1 promoter transactivation by Abeta42. J Biol Chem 2008, 283:10037-10047.

33. Zhao J, Fu Y, Yasvoina M, Shao P, Hitt B, O'Connor T, Logan S, Maus E, Citron M, Berry R, et al: Beta-site amyloid precursor protein cleaving enzyme 1 levels become elevated in neurons around amyloid plaques: implications for Alzheimer's disease pathogenesis. J Neurosci 2007, 27:3639-3649

34. Faghihi MA, Modarresi F, Khalil AM, Wood DE, Sahagan BG, Morgan TE, Finch CE, St Laurent G 3rd, Kenny PJ, Wahlestedt C: Expression of a noncoding RNA is elevated in Alzheimer's disease and drives rapid feedforward regulation of beta-secretase. Nat Med 2008, 14:723-730.

35. Li Y, Cam J, Bu G: Low-density lipoprotein receptor family: endocytosis and signal transduction. Mol Neurobiol 2001, 23:53-67.

36. Vetrivel $\mathrm{KS}$, Zhang $\mathrm{YW}, \mathrm{Xu} \mathrm{H}$, Thinakaran G: Pathological and physiological functions of presenilins. Mol Neurodegener 2006, 1:4.

37. De Strooper B: Aph-1, Pen-2, and Nicastrin with Presenilin generate an active gamma-Secretase complex. Neuron 2003, 38:9-12.

38. Koo EH, Kopan R: Potential role of presenilin-regulated signaling pathways in sporadic neurodegeneration. Nat Med 2004, 10(Suppl):S26-S33.
39. Larner AJ, Doran M: Clinical phenotypic heterogeneity of Alzheimer's disease associated with mutations of the presenilin-1 gene. J Neurol 2006, 253:139-158.

40. Hardy J, Selkoe DJ: The amyloid hypothesis of Alzheimer's disease: progress and problems on the road to therapeutics. Science 2002, 297:353-356.

41. Qian S, Jiang P, Guan XM, Singh G, Trumbauer ME, Yu H, Chen HY, Van de Ploeg LH, Zheng H: Mutant human presenilin 1 protects presenilin 1 null mouse against embryonic lethality and elevates Abeta1-42/43 expression. Neuron 1998, 20:611-617.

42. Saura CA, Choi SY, Beglopoulos V, Malkani S, Zhang D, Shankaranarayana Rao BS, Chattarji S, Kelleher RJ 3rd, Kandel ER, Duff K, et al: Loss of presenilin function causes impairments of memory and synaptic plasticity followed by age-dependent neurodegeneration. Neuron 2004, 42:23-36.

43. Feng $R$, Wang $H$, Wang J, Shrom D, Zeng $X$, Tsien JZ: Forebrain degeneration and ventricle enlargement caused by double knockout of Alzheimer's presenilin-1 and presenilin-2. Proc Natl Acad Sci USA 2004, 101:8162-8167.

44. Beglopoulos V, Sun X, Saura CA, Lemere CA, Kim RD, Shen J: Reduced betaamyloid production and increased inflammatory responses in presenilin conditional knock-out mice. J Biol Chem 2004, 279:46907-46914.

45. Chen Q, Nakajima A, Choi SH, Xiong X, Tang YP: Loss of presenilin function causes Alzheimer's disease-like neurodegeneration in the mouse. J Neurosci Res 2008, 86:1615-1625.

46. Dong S, Li C, Wu P, Tsien JZ, Hu Y: Environment enrichment rescues the neurodegenerative phenotypes in presenilins-deficient mice. Eur J Neurosci 2007, 26:101-112.

47. Amtul Z, Lewis PA, Piper S, Crook R, Baker M, Findlay K, Singleton A, Hogg $M$, Younkin L, Younkin SG, et al: A presenilin 1 mutation associated with familial frontotemporal dementia inhibits gamma-secretase cleavage of APP and notch. Neurobiol Dis 2002, 9:269-273.

48. Dermaut B, Kumar-Singh S, Engelborghs S, Theuns J, Rademakers R, Saerens $J$, Pickut BA, Peeters K, van den Broeck M, Vennekens K, et al: A novel presenilin 1 mutation associated with Pick's disease but not betaamyloid plaques. Ann Neurol 2004, 55:617-626.

49. Raux G, Gantier R, Thomas-Anterion C, Boulliat J, Verpillat P, Hannequin D, Brice A, Frebourg T, Campion D: Dementia with prominent frontotemporal features associated with L113P presenilin 1 mutation. Neurology 2000, 55:1577-1578.

50. Bai G, Chivatakarn O, Bonanomi D, Lettieri K, Franco L, Xia C, Stein E, Ma L, Lewcock JW, Pfaff SL: Presenilin-dependent receptor processing is required for axon guidance. Cell 2011, 144:106-118.

51. Shen J, Kelleher RJ III: The presenilin hypothesis of Alzheimer's disease: Evidence for a loss-of-function pathogenic mechanism. PNAS 2007, 104:403-409.

52. Wang R, Tang P, Wang P, Boissy RE, Zheng H: Regulation of tyrosinase trafficking and processing by presenilins: partial loss of function by familial Alzheimer's disease mutation. Proc Natl Acad Sci USA 2006, 103:353-358.

53. Kang DE, Soriano S, Frosch MP, Collins T, Naruse S, Sisodia SS, Leibowitz G, Levine F, Koo EH: Presenilin 1 facilitates the constitutive turnover of betacatenin: differential activity of Alzheimer's disease-linked PS1 mutants in the beta-catenin-signaling pathway. J Neurosci 1999, 19:4229-4237.

54. Landman N, Jeong SY, Shin SY, Voronov SV, Serban G, Kang MS, Park MK, Di Paolo G, Chung S, Kim TW: Presenilin mutations linked to familial Alzheimer's disease cause an imbalance in phosphatidylinositol 4,5bisphosphate metabolism. Proc Natl Acad Sci USA 2006, 103:19524-19529.

55. Tu H, Nelson O, Bezprozvanny A, Wang Z, Lee SF, Hao YH, Serneels L, De Strooper B, Yu G, Bezprozvanny l: Presenilins form ER Ca2+ leak channels, a function disrupted by familial Alzheimer's disease-linked mutations. Cell 2006, 126:981-993.

56. Baki L, Neve RL, Shao Z, Shioi J, Georgakopoulos A, Robakis NK: Wild-type but not FAD mutant presenilin-1 prevents neuronal degeneration by promoting phosphatidylinositol 3-kinase neuroprotective signaling. J Neurosci 2008, 28:483-490.

57. Pratt KG, Zimmerman EC, Cook DG, Sullivan JM: Presenilin 1 regulates homeostatic synaptic scaling through Akt signaling. Nat Neurosci 2011, 14:1112-1114

58. Lazarov O, Morfini GA, Pigino G, Gadadhar A, Chen X, Robinson J, Ho H, Brady ST, Sisodia SS: Impairments in fast axonal transport and motor 
neuron deficits in transgenic mice expressing familial Alzheimer's disease-linked mutant presenilin 1. J Neurosci 2007, 27:7011-7020.

59. Durkin JT, Murthy S, Husten EJ, Trusko SP, Savage MJ, Rotella DP, Greenberg $B D$, Siman R: Rank-order of potencies for inhibition of the secretion of abeta40 and abeta42 suggests that both are generated by a single gamma-secretase. J Biol Chem 1999, 274:20499-20504.

60. Sato T, Dohmae N, Qi Y, Kakuda N, Misonou H, Mitsumori R, Maruyama H, Koo EH, Haass C, Takio K, et al: Potential link between amyloid betaprotein 42 and C-terminal fragment gamma 49-99 of beta-amyloid precursor protein. J Biol Chem 2003, 278:24294-24301.

61. Zhang L, Song L, Terracina G, Liu Y, Pramanik B, Parker E: Biochemical characterization of the gamma-secretase activity that produces betaamyloid peptides. Biochemistry 2001, 40:5049-5055.

62. Xu Q, Bernardo A, Walker D, Kanegawa T, Mahley RW, Huang Y: Profile and Regulation of Apolipoprotein E (ApoE) expression in the CNS in mice with targeting of green fluorescent protein gene to the ApoE locus. J Neurosci 2006, 26:4985-4994.

63. Xu Q, Li Y, Cyras C, Sanan DA, Cordell B: Isolation and characterization of apolipoproteins from murine microglia. Identification of a low density lipoprotein-like apolipoprotein j-rich but E-poor spherical particle. J Biol Chem 2000, 275:31770-31777.

64. Shi J, Zhao CB, Vollmer TL, Tyry TM, Kuniyoshi SM: APOE epsilon 4 allele is associated with cognitive impairment in patients with multiple sclerosis. Neurology 2008, 70:185-190.

65. de Frias CM, Bunce D, Wahlin A, Adolfsson R, Sleegers K, Cruts M, Van Broeckhoven C, Nilsson LG: Cholesterol and triglycerides moderate the effect of apolipoprotein $\mathrm{E}$ on memory functioning in older adults. J Gerontol B Psychol Sci Soc Sci 2007, 62:P112-P118.

66. Mahley RW, Weisgraber KH, Huang Y: Apolipoprotein E4: a causative factor and therapeutic target in neuropathology, including Alzheimer's disease. Proc Natl Acad Sci USA 2006, 103:5644-5651.

67. Harris FM, Brecht WJ, Xu Q, Tesseur I, Kekonius L, Wyss-Coray T, Fish JD, Masliah E, Hopkins PC, Scearce-Levie K, et al: Carboxyl-terminal-truncated apolipoprotein E4 causes Alzheimer's disease-like neurodegeneration and behavioral deficits in transgenic mice. Proc Natl Acad Sci USA 2003, 100:10966-10971.

68. DeMattos RB, Cirrito JR, Parsadanian M, May PC, O'Dell MA, Taylor JW, Harmony JA, Aronow BJ, Bales KR, Paul SM, Holtzman DM: ApoE and clusterin cooperatively suppress Abeta levels and deposition: evidence that ApoE regulates extracellular Abeta metabolism in vivo. Neuron 2004, 41:193-202

69. Kim J, Basak JM, Holtzman DM: The role of apolipoprotein E in Alzheimer's disease. Neuron 2009, 63:287-303.

70. Sadowski MJ, Pankiewicz J, Scholtzova H, Mehta PD, Prelli F, Quartermain D, Wisniewski T: Blocking the apolipoprotein E/amyloid-beta interaction as a potential therapeutic approach for Alzheimer's disease. Proc Natl Acad Sci USA 2006, 103:18787-18792.

71. Cao D, Lu H, Lewis TL, Li L: Intake of sucrose-sweetened water induces insulin resistance and exacerbates memory deficits and amyloidosis in a transgenic mouse model of Alzheimer disease. J Biol Chem 2007, 282:36275-36282.

72. Cramer PE, Cirrito JR, Wesson DW, Lee CY, Karlo JC, Zinn AE, Casali BT, Restivo JL, Goebel WD, James MJ, et al: ApoE-directed therapeutics rapidly clear beta-amyloid and reverse deficits in AD mouse models. Science 2012, 335:1503-1506.

73. Holtzman DM: In vivo effects of ApoE and clusterin on amyloid-beta metabolism and neuropathology. J Mol Neurosci 2004, 23:247-254.

74. Jiang Q, Lee CY, Mandrekar S, Wilkinson B, Cramer P, Zelcer N, Mann K, Lamb B, Willson TM, Collins JL, et al: ApoE promotes the proteolytic degradation of Abeta. Neuron 2008, 58:681-693.

75. Ye S, Huang Y, Mullendorff K, Dong L, Giedt G, Meng EC, Cohen FE, Kuntz ID, Weisgraber KH, Mahley RW: Apolipoprotein (apo) E4 enhances amyloid beta peptide production in cultured neuronal cells: apoE structure as a potential therapeutic target. Proc Natl Acad Sci USA 2005, 102:18700-18705.

76. Wolozin B: Cholesterol and the biology of Alzheimer's disease. Neuron 2004, 41:7-10.

77. Belinson H, Lev D, Masliah E, Michaelson DM: Activation of the amyloid cascade in apolipoprotein E4 transgenic mice induces lysosomal activation and neurodegeneration resulting in marked cognitive deficits. J Neurosci 2008, 28:4690-4701.
78. Levi O, Dolev I, Belinson H, Michaelson DM: Intraneuronal amyloid-beta plays a role in mediating the synergistic pathological effects of apoE4 and environmental stimulation. J Neurochem 2007, 103:1031-1040.

79. Brecht WJ, Harris FM, Chang S, Tesseur I, Yu GQ, Xu Q, Dee Fish J, WyssCoray T, Buttini M, Mucke L, et al: Neuron-specific apolipoprotein e4 proteolysis is associated with increased tau phosphorylation in brains of transgenic mice. J Neurosci 2004, 24:2527-2534.

80. Cui $Y$, Huang $M, H e Y$, Zhang $S$, Luo $Y$ : Genetic ablation of apolipoprotein A-IV accelerates Alzheimer's disease pathogenesis in a mouse model. Am J Pathol 2011, 178:1298-1308.

81. Selkoe DJ: Clearing the brain's amyloid cobwebs. Neuron 2001, 32:177-180

82. Miners JS, Baig S, Palmer J, Palmer LE, Kehoe PG, Love S: Abeta-degrading enzymes in Alzheimer's disease. Brain Pathol 2008, 18:240-252.

83. Hellstrom-Lindahl E, Ravid R, Nordberg A: Age-dependent decline of neprilysin in Alzheimer's disease and normal brain: inverse correlation with A beta levels. Neurobiol Aging 2008, 29:210-221.

84. Hersh LB, Rodgers DW: Neprilysin and amyloid beta peptide degradation. Curr Alzheimer Res 2008, 5:225-231.

85. Miners JS, Van Helmond Z, Chalmers K, Wilcock G, Love S, Kehoe PG: Decreased expression and activity of neprilysin in Alzheimer disease are associated with cerebral amyloid angiopathy. J Neuropathol Exp Neurol 2006, 65:1012-1021.

86. Yasojima K, Akiyama H, McGeer EG, McGeer PL: Reduced neprilysin in high plaque areas of Alzheimer brain: a possible relationship to deficient degradation of beta-amyloid peptide. Neurosci Lett 2001, 297:97-100.

87. Chander $\mathrm{H}$, Chauhan A, Chauhan V: Binding of proteases to fibrillar amyloid-beta protein and its inhibition by Congo red. $J$ Alzheimers Dis 2007, 12:261-269.

88. El-Amouri SS, Zhu H, Yu J, Marr R, Verma IM, Kindy MS: Neprilysin: an enzyme candidate to slow the progression of Alzheimer's disease. Am J Pathol 2008, 172:1342-1354.

89. lijima-Ando K, Hearn SA, Granger L, Shenton C, Gatt A, Chiang H-C, Hakker I, Zhong $Y$, lijima $K$ : Overexpression of neprilysin reduces Alzheimer amyloid-\{beta\}42 (A\{beta\}42)-induced neuron loss and intraneuronal $A$ \{beta\}42 deposits but causes a reduction in CAMP-responsive elementbinding protein-mediated transcription, age-dependent axon pathology, and premature death in drosophila. J Biol Chem 2008, 283:19066-19076.

90. Meilandt WJ, Cisse M, Ho K, Wu T, Esposito LA, Scearce-Levie K, Cheng IH, Yu GQ, Mucke L: Neprilysin overexpression inhibits plaque formation but fails to reduce pathogenic Abeta oligomers and associated cognitive deficits in human amyloid precursor protein transgenic mice. J Neurosci 2009, 29:1977-1986.

91. Edbauer D, Willem M, Lammich S, Steiner H, Haass C: Insulin-degrading enzyme rapidly removes the beta-amyloid precursor protein intracellular domain (AICD). J Biol Chem 2002, 277:13389-13393.

92. Farris W, Mansourian S, Chang Y, Lindsley L, Eckman EA, Frosch MP, Eckman $C B$, Tanzi RE, Selkoe DJ, Guenette S: Insulin-degrading enzyme regulates the levels of insulin, amyloid beta-protein, and the beta-amyloid precursor protein intracellular domain in vivo. Proc Natl Acad Sci USA 2003, 100:4162-4167.

93. Ertekin-Taner N, Graff-Radford N, Younkin LH, Eckman C, Baker M, Adamson J, Ronald J, Blangero J, Hutton M, Younkin SG: Linkage of plasma Abeta42 to a quantitative locus on chromosome 10 in late-onset Alzheimer's disease pedigrees. Science 2000, 290:2303-2304.

94. Mueller JC, Riemenschneider M, Schoepfer-Wendels A, Gohlke H, Konta L, Friedrich P, Illig T, Laws SM, Forstl H, Kurz A: Weak independent association signals between IDE polymorphisms, Alzheimer's disease and cognitive measures. Neurobiol Aging 2007, 28:727-734

95. Vepsalainen S, Parkinson M, Helisalmi S, Mannermaa A, Soininen H, Tanzi RE, Bertram L, Hiltunen M: Insulin-degrading enzyme is genetically associated with Alzheimer's disease in the Finnish population. J Med Genet 2007, 44:606-608.

96. Cook DG, Leverenz JB, McMillan PJ, Kulstad JJ, Ericksen S, Roth RA, Schellenberg GD, Jin LW, Kovacina KS, Craft S: Reduced hippocampal insulin-degrading enzyme in late-onset Alzheimer's disease is associated with the apolipoprotein E-epsilon4 allele. Am J Pathol 2003, 162:313-319.

97. Zhao Z, Xiang Z, Haroutunian V, Buxbaum JD, Stetka B, Pasinetti GM: Insulin degrading enzyme activity selectively decreases in the hippocampal formation of cases at high risk to develop Alzheimer's disease. Neurobiol Aging 2007, 28:824-830. 
98. Kim M, Hersh LB, Leissring MA, Ingelsson M, Matsui T, Farris W, Lu A, Hyman BT, Selkoe DJ, Bertram L, Tanzi RE: Decreased catalytic activity of the insulin-degrading enzyme in chromosome 10-linked Alzheimer disease families. J Biol Chem 2007, 282:7825-7832.

99. Vepsalainen S, Hiltunen M, Helisalmi S, Wang J, van Groen T, Tanila H, Soininen $\mathrm{H}$ : Increased expression of Abeta degrading enzyme IDE in the cortex of transgenic mice with Alzheimer's disease-like neuropathology. Neurosci Lett 2008, 438:216-220.

100. Leal MC, Dorfman VB, Gamba AF, Frangione B, Wisniewski T, Castano EM, Sigurdsson EM, Morelli L: Plaque-associated overexpression of insulindegrading enzyme in the cerebral cortex of aged transgenic tg2576 mice with Alzheimer pathology. I Neuropathol Exp Neurol 2006, 65:976-987.

101. Bernstein HG, Ansorge S, Riederer P, Reiser M, Frolich L, Bogerts B: Insulindegrading enzyme in the Alzheimer's disease brain: prominent localization in neurons and senile plaques. Neurosci Lett 1999, 263:161-164.

102. Zhao L, Yao J, Mao Z, Chen S, Wang Y, Brinton RD: 17beta-Estradiol regulates insulin-degrading enzyme expression via an ERbeta/PI3-K pathway in hippocampus: relevance to Alzheimer's prevention. Neurobiol Aging 2011, 32:1949-1963.

103. Carson JA, Turner AJ: Beta-amyloid catabolism: roles for neprilysin (NEP) and other metallopeptidases? J Neurochem 2002, 81:1-8.

104. Llovera RE, de Tullio M, Alonso LG, Leissring MA, Kaufman SB, Roher AE, de Prat Gay G, Morelli L, Castano EM: The catalytic domain of insulindegrading enzyme forms a denaturant-resistant complex with amyloid \{beta\} peptide: implications for Alzheimer disease pathogenesis. J Biol Chem 2008, 283:17039-17048.

105. Jean L, Thomas B, Tahiri-Alaoui A, Shaw M, Vaux DJ: Heterologous amyloid seeding: revisiting the role of acetylcholinesterase in Alzheimer's disease. PLoS One 2007, 2:e652.

106. Sun MK, Alkon DL: Links between Alzheimer's disease and diabetes. Drugs Today (Barc) 2006, 42:481-489.

107. Leibson CL, Rocca WA, Hanson VA, Cha R, Kokmen E, O'Brien PC, Palumbo PJ: Risk of dementia among persons with diabetes mellitus: a population-based cohort study. Am J Epidemiol 1997, 145:301-308.

108. Ho L, Qin W, Pompl PN, Xiang Z, Wang J, Zhao Z, Peng Y, Cambareri G, Rocher A, Mobbs CV, et al: Diet-induced insulin resistance promotes amyloidosis in a transgenic mouse model of Alzheimer's disease. FASEB J 2004, 18:902-904.

109. Zhao L, Teter B, Morihara T, Lim GP, Ambegaokar SS, Ubeda OJ, Frautschy SA, Cole GM: Insulin-degrading enzyme as a downstream target of insulin receptor signaling cascade: implications for Alzheimer's disease intervention. J Neurosci 2004, 24:11120-11126.

110. Crouch PJ, Harding SM, White AR, Camakaris J, Bush Al, Masters CL: Mechanisms of Abeta mediated neurodegeneration in Alzheimer's disease. Int J Biochem Cell Biol 2008, 40:181-198.

111. Moreno H, Yu E, Pigino G, Hernandez Al, Kim N, Moreira JE, Sugimori M, Llinas RR: Synaptic transmission block by presynaptic injection of oligomeric amyloid beta. Proc Natl Acad Sci 2009, 106:5901-5906.

112. Lee HG, Zhu X, Castellani RJ, Nunomura A, Perry G, Smith MA: Amyloidbeta in Alzheimer disease: the null versus the alternate hypotheses. J Pharmacol Exp Ther 2007, 321:823-829.

113. Verkkoniemi A, Kalimo H, Paetau A, Somer M, Iwatsubo T, Hardy J, Haltia M: Variant Alzheimer disease with spastic paraparesis: neuropathological phenotype. J Neuropathol Exp Neurol 2001, 60:483-492.

114. Jacobsen JS, Wu CC, Redwine JM, Comery TA, Arias R, Bowlby M, Martone R, Morrison JH, Pangalos MN, Reinhart PH, Bloom FE: Early-onset behavioral and synaptic deficits in a mouse model of Alzheimer's disease. Proc Natl Acad Sci USA 2006, 103:5161-5166.

115. Schmitz C, Rutten BP, Pielen A, Schafer S, Wirths O, Tremp G, Czech C, Blanchard V, Multhaup G, Rezaie P, et al: Hippocampal neuron loss exceeds amyloid plaque load in a transgenic mouse model of Alzheimer's disease. Am J Pathol 2004, 164:1495-1502.

116. LaFerla FM, Green KN, Oddo S: Intracellular amyloid-beta in Alzheimer's disease. Nat Rev Neurosci 2007, 8:499-509.

117. Chui DH, Tanahashi H, Ozawa K, Ikeda S, Checler F, Ueda O, Suzuki H, Araki W, Inoue H, Shirotani K, et al: Transgenic mice with Alzheimer presenilin 1 mutations show accelerated neurodegeneration without amyloid plaque formation. Nat Med 1999, 5:560-564.
118. Billings LM, Oddo S, Green KN, McGaugh JL, LaFerla FM: Intraneuronal Abeta causes the onset of early Alzheimer's disease-related cognitive deficits in transgenic mice. Neuron 2005, 45:675-688.

119. Oddo S, Caccamo A, Shepherd JD, Murphy MP, Golde TE, Kayed R, Metherate R, Mattson MP, Akbari Y, LaFerla FM: Triple-transgenic model of Alzheimer's disease with plaques and tangles: intracellular Abeta and synaptic dysfunction. Neuron 2003, 39:409-421.

120. Cruz JC, Kim D, Moy LY, Dobbin MM, Sun X, Bronson RT, Tsai LH: p25/ cyclin-dependent kinase 5 induces production and intraneuronal accumulation of amyloid beta in vivo. J Neurosci 2006, 26:10536-10541.

121. Knobloch M, Konietzko U, Krebs DC, Nitsch RM: Intracellular Abeta and cognitive deficits precede beta-amyloid deposition in transgenic arcAbeta mice. Neurobiol Aging 2007, 28:1297-1306.

122. Oakley H, Cole SL, Logan S, Maus E, Shao P, Craft J, Guillozet-Bongaarts A, Ohno M, Disterhoft J, Van Eldik L, et al: Intraneuronal beta-Amyloid aggregates, neurodegeneration, and neuron loss in transgenic mice with five familial Alzheimer's disease mutations: potential factors in amyloid plaque formation. J Neurosci 2006, 26:10129-10140.

123. Suo Z, Cox AA, Bartelli N, Rasul I, Festoff BW, Premont RT, Arendash GW: GRK5 deficiency leads to early Alzheimer-like pathology and working memory impairment. Neurobiol Aging 2007, 28:1873-1888.

124. Van Broeck B, Vanhoutte G, Pirici D, Van Dam D, Wils H, Cuijt I, Vennekens K, Zabielski M, Michalik A, Theuns J, et al: Intraneuronal amyloid beta and reduced brain volume in a novel APP T714I mouse model for Alzheimer's disease. Neurobiol Aging 2008, 29:241-252.

125. D'Andrea MR, Nagele RG, Wang HY, Lee DH: Consistent immunohistochemical detection of intracellular beta-amyloid42 in pyramidal neurons of Alzheimer's disease entorhinal cortex. Neurosci Lett 2002, 333:163-166.

126. Klyubin I, Betts V, Welzel AT, Blennow K, Zetterberg H, Wallin A, Lemere CA, Cullen WK, Peng Y, Wisniewski T, et al: Amyloid beta protein dimercontaining human CSF disrupts synaptic plasticity: prevention by systemic passive immunization. J Neurosci 2008, 28:4231-4237.

127. King ME, Kan HM, Baas PW, Erisir A, Glabe CG, Bloom GS: Tau-dependent microtubule disassembly initiated by prefibrillar beta-amyloid. J Cell Biol 2006, 175:541-546.

128. Nimmrich V, Grimm C, Draguhn A, Barghorn S, Lehmann A, Schoemaker H, Hillen H, Gross G, Ebert U, Bruehl C: Amyloid beta oligomers (A beta(1-42) globulomer) suppress spontaneous synaptic activity by inhibition of P/Q-type calcium currents. J Neurosci 2008, 28:788-797.

129. De Felice FG, Velasco PT, Lambert MP, Viola K, Fernandez SJ, Ferreira ST, Klein WL: Abeta oligomers induce neuronal oxidative stress through an $\mathrm{N}$-methyl-D-aspartate receptor-dependent mechanism that is blocked by the Alzheimer drug memantine. J Biol Chem 2007, 282:11590-11601.

130. Shankar GM, Bloodgood BL, Townsend M, Walsh DM, Selkoe DJ, Sabatini BL: Natural oligomers of the Alzheimer amyloid-beta protein induce reversible synapse loss by modulating an NMDA-type glutamate receptor-dependent signaling pathway. J Neurosci 2007, 27:2866-2875.

131. Resende R, Moreira PI, Proenca T, Deshpande A, Busciglio J, Pereira C, Oliveira CR: Brain oxidative stress in a triple-transgenic mouse model of Alzheimer disease. Free Radic Biol Med 2008, 44:2051-2057.

132. Eckerta A, Hauptmannb S, Scherpingb I, Rheina V, Müller-Spahna F, Götzc J, Müllerb W: Soluble beta-amyloid leads to mitochondrial defects in amyloid precursor protein and Tau Transgenic mice. Neurodegenerative Dis 2008, 5:157-159.

133. Chimon S, Shaibat MA, Jones CR, Calero DC, Aizezi B, Ishii Y: Evidence of fibril-like beta-sheet structures in a neurotoxic amyloid intermediate of Alzheimer's beta-amyloid. Nat Struct Mol Biol 2007, 14:1157-1164.

134. Walsh DM, Selkoe DJ: Deciphering the molecular basis of memory failure in Alzheimer's disease. Neuron 2004, 44:181-193.

135. Lacor PN, Buniel MC, Furlow PW, Clemente AS, Velasco PT, Wood M, Viola $\mathrm{KL}$, Klein WL: Abeta oligomer-induced aberrations in synapse composition, shape, and density provide a molecular basis for loss of connectivity in Alzheimer's disease. J Neurosci 2007, 27:796-807.

136. Barry AE, Klyubin I, Mc Donald JM, Mably AJ, Farrell MA, Scott M, Walsh DM, Rowan MJ: Alzheimer's disease brain-derived amyloid--mediated inhibition of LTP in vivo is prevented by immunotargeting cellular prion protein. J Neurosci 2011, 31:7259-7263.

137. Alexandru A, Jagla W, Graubner S, Becker A, Bauscher C, Kohlmann S, Sedlmeier R, Raber KA, Cynis H, Ronicke R, et al: Selective hippocampal neurodegeneration in transgenic mice expressing small amounts of 
truncated a is induced by pyroglutamate-a formation. J Neurosci 2011, 31:12790-12801.

138. Um JW, Nygaard HB, Heiss JK, Kostylev MA, Stagi M, Vortmeyer A, Wisniewski T, Gunther EC, Strittmatter SM: Alzheimer amyloid-beta oligomer bound to postsynaptic prion protein activates Fyn to impair neurons. Nat Neurosci 2012, 15:1227-1235.

139. Lesne S, Koh MT, Kotilinek L, Kayed R, Glabe CG, Yang A, Gallagher M, Ashe $\mathrm{KH}$ : A specific amyloid-beta protein assembly in the brain impairs memory. Nature 2006, 440:352-357.

140. Cheng IH, Scearce-Levie K, Legleiter J, Palop JJ, Gerstein H, Bien-Ly N, Puolivali J, Lesne S, Ashe KH, Muchowski PJ, Mucke L: Accelerating amyloid-beta fibrillization reduces oligomer levels and functional deficits in Alzheimer disease mouse models. J Biol Chem 2007, 282:23818-23828.

141. Walsh DM, Klyubin I, Fadeeva JV, Cullen WK, Anwyl R, Wolfe MS, Rowan MJ, Selkoe DJ: Naturally secreted oligomers of amyloid beta protein potently inhibit hippocampal long-term potentiation in vivo. Nature 2002, 416:535-539.

142. Abramov E, Dolev I, Fogel H, Ciccotosto GD, Ruff E, Slutsky I: Amyloid- $\beta$ as a positive endogenous regulator of release probability at hippocampal synapses. Nat Neurosci 2009, 12:1567-1576.

143. Palop JJ, Chin J, Roberson ED, Wang J, Thwin MT, Bien-Ly N, Yoo J, Ho KO, Yu GQ, Kreitzer A, et al: Aberrant excitatory neuronal activity and compensatory remodeling of inhibitory hippocampal circuits in mouse models of Alzheimer's disease. Neuron 2007, 55:697-711.

144. Meyer-Luehmann M, Spires-Jones TL, Prada C, Garcia-Alloza M, de Calignon A, Rozkalne A, Koenigsknecht-Talboo J, Holtzman DM, Bacskai BJ, Hyman BT: Rapid appearance and local toxicity of amyloid-beta plaques in a mouse model of Alzheimer's disease. Nature 2008, 451:720-724.

145. Simard AR, Soulet D, Gowing G, Julien JP, Rivest S: Bone marrow-derived microglia play a critical role in restricting senile plaque formation in Alzheimer's disease. Neuron 2006, 49:489-502.

146. Fiala M, Cribbs DH, Rosenthal M, Bernard G: Phagocytosis of amyloid-beta and inflammation: two faces of innate immunity in Alzheimer's disease. J Alzheimers Dis 2007, 11:457-463.

147. Bolmont T, Haiss F, Eicke D, Radde R, Mathis CA, Klunk WE, Kohsaka S, Jucker M, Calhoun ME: Dynamics of the microglial/amyloid interaction indicate a role in plaque maintenance. J Neurosci 2008, 28:4283-4292.

148. Medeiros R, Prediger RD, Passos GF, Pandolfo P, Duarte FS, Franco JL, Dafre AL, Di Giunta G, Figueiredo CP, Takahashi RN, et al: Connecting TNF-alpha signaling pathways to iNOS expression in a mouse model of Alzheimer's disease: relevance for the behavioral and synaptic deficits induced by amyloid beta protein. J Neurosci 2007, 27:5394-5404.

149. Town T, Laouar Y, Pittenger C, Mori T, Szekely CA, Tan J, Duman RS, Flavell RA: Blocking TGF-beta-Smad2/3 innate immune signaling mitigates Alzheimer-like pathology. Nat Med 2008, 14:681-687.

150. Tesseur I, Zou K, Esposito L, Bard F, Berber E, Can JV, Lin AH, Crews L, Tremblay P, Mathews $P$, et al: Deficiency in neuronal TGF-beta signaling promotes neurodegeneration and Alzheimer's pathology. J Clin Invest 2006, 116:3060-3069.

151. Caraci F, Battaglia G, Bruno V, Bosco P, Carbonaro V, Giuffrida ML, Drago F, Sortino MA, Nicoletti F, Copani A: TGF- $\beta 1$ pathway as a new target for neuroprotection in Alzheimer's disease. CNS Neurosci Ther 2011, 17:237-249.

doi:10.1186/2047-9158-1-18

Cite this article as: Dong et al: Advances in the pathogenesis of Alzheimer's disease: a re-evaluation of amyloid cascade hypothesis. Translational Neurodegeneration 2012 1:18.

\section{Submit your next manuscript to BioMed Central and take full advantage of:}

- Convenient online submission

- Thorough peer review

- No space constraints or color figure charges

- Immediate publication on acceptance

- Inclusion in PubMed, CAS, Scopus and Google Scholar

- Research which is freely available for redistribution

Submit your manuscript at www.biomedcentral.com/submit
Ciomed Central 